Literary Hispanophobia and Hispanophilia in Britain and the Low Countries (1550-1850) 


\section{Heritage and Memory Studies}

This ground-breaking series examines the dynamics of heritage and memory from a transnational, interdisciplinary and integrated approach. Monographs or edited volumes critically interrogate the politics of heritage and dynamics of memory, as well as the theoretical implications of landscapes and mass violence, nationalism and ethnicity, heritage preservation and conservation, archaeology and (dark) tourism, diaspora and postcolonial memory, the power of aesthetics and the art of absence and forgetting, mourning and performative re-enactments in the present.

Series Editors

Ihab Saloul and Rob van der Laarse, University of Amsterdam, The Netherlands

Advisory Board

Patrizia Violi, University of Bologna, Italy

Britt Baillie, Cambridge University, United Kingdom

Michael Rothberg, University of Illinois, USA

Marianne Hirsch, Columbia University, USA

Frank van Vree, University of Amsterdam, The Netherlands 


\title{
Literary Hispanophobia and Hispanophilia in Britain and the Low Countries (1550-1850)
}

\author{
Edited by \\ Yolanda Rodríguez Pérez
}


This research has been made possible with the generous support of the Netherlands Organisation for Scientific Research (NWO) within the 'Innovational Research Incentives Scheme Vidi'.

Cover illustration designed by David Durà

Cover design: Coördesign, Leiden

Lay-out: Crius Group, Hulshout

$\begin{array}{ll}\text { ISBN } & 978 \text { 94 62989375 } \\ \text { e-ISBN } & 978 \text { 90 } 48541935 \\ \text { DOI } & 10.5117 / 9789462989375 \\ \text { NUR } & 685\end{array}$

\section{(2) (1) $\Theta \Theta$}

Creative Commons License CC BY NC ND (http://creativecommons.org/licenses/by-nc-nd/3.o)

@ All authors / Amsterdam University Press B.V., Amsterdam 2020

Some rights reserved. Without limiting the rights under copyright reserved above, any part of this book may be reproduced, stored in or introduced into a retrieval system, or transmitted, in any form or by any means (electronic, mechanical, photocopying, recording or otherwise).

Every effort has been made to obtain permission to use all copyrighted illustrations reproduced in this book. Nonetheless, whosoever believes to have rights to this material is advised to contact the publisher. 